\title{
Acta
Biochimica
Polonica
}

Vol. 52 No. 1/2005

$149-165$

QUARTERLY

\section{Mismatch dependent uracil/thymine-DNA glycosylases excise exocyclic hydroxyethano and hydroxypropano cytosine adducts ${ }^{*}$}

\author{
Ewa Borys-Brzywczy ${ }^{1}$, Katarzyna D. Arczewska ${ }^{1}$, Murat Saparbaev², Ulrike \\ Hardeland $^{3}$, Primo Schär ${ }^{4}$ and Jarosław T. Kuśmierek ${ }^{1 凶}$ \\ ${ }^{1}$ Institute of Biochemistry and Biophysics, Polish Academy of Sciences, Warszawa, Poland; \\ ${ }^{2}$ Groupe "Réparation de l'ADN", UMR 8532 CNRS, Institut Gustave Roussy, Villejuif, Cedex, \\ France; ${ }^{3}$ Biochemie-Zentrum-Heidelberg, University of Heidelberg, Heidelberg, Germany; \\ ${ }^{4}$ Institute of Biochemistry and Genetics, University of Basel, Basel, Switzerland
}

Received: 19 November, 2004; accepted: 03 March, 2005

Key words: exocyclic cytosine adducts, base excision repair, E. coli mismatch uracil-DNA glycosylase, human thymine-DNA glycosylase, $S$. pombe Thp1p glycosylase

\begin{abstract}
Exocyclic adducts of DNA bases, such as etheno- and hydroxyalkano- ones, are generated by a variety of bifunctional agents, including endogenously formed products of lipid peroxidation. In this work we selectively modified cytosines in the 5 '-d(TTT TTT CTT TTT CTT TTT CTT TTT T)-3' oligonucleotide using: chloroacetaldehyde to obtain $3, \mathrm{~N}^{4}-\alpha$-hydroxyethano- (HEC) and $3, \mathrm{~N}^{4}$-etheno- $(\varepsilon \mathrm{C})$, acrolein to obtain
\end{abstract}

\footnotetext{
${ }^{*}$ This work was supported by grants from: the State Committee for Scientific Research (KBN, Poland) (6 P04A 06210; E.B.-B. and J.T.K.), the European Community (QLK4-2000-00286; E.B.-B., K.D.A., M.S. and J.T.K.) and the Swiss National Science Foundation (SNF-3100-053826; P.S. and U.H.). The studies were conducted within the framework of the activity of the Center of Excellence in Molecular Biotechnology, Institute of Biochemistry and Biophysics PAS (WP 10).

${ }^{\otimes}$ Correspondence to: J.T. Kuśmierek, Institute of Biochemistry and Biophysics, Polish Academy of Sciences, A. Pawińskiego 5A, 02-106 Warszawa, Poland; tel.: (48 22) 592 3338; fax: (48 22) 658 4636; e-mail: jareq@ibb.waw.pl

Abbreviations: ACR, acrolein; AlkA, E. coli 3-methyladenine-DNA glycosylase II; ANPG, $N$-alkylpurine-DNA glycosylase; BER, base excision repair; CAA, chloroacetaldehyde; CRA, crotonaldehyde; $\varepsilon \mathrm{C}$, see Fig. 1; HEC, see Fig.1; HNE, trans-4-hydroxy-2-nonenal; HPC, see Fig. 1; LPO, lipid peroxidation; mHPC, see Fig. 1; Mug, E. coli mismatch uracil-DNA glycosylase; NER, nucleotide excision repair; Nth, thymine glycol glycosylase, E. coli endonuclease III; TBE buffer, $90 \mathrm{mM}$ Tris/boric acid, $2 \mathrm{mM}$ EDTA, $\mathrm{pH}$ 8.3; TE buffer, $10 \mathrm{mM}$ Tris/HCl, $1 \mathrm{mM}$ EDTA, $\mathrm{pH}$ 8.0; TDG, mismatch thymine-DNA glycosylase; Thp1p, TDG homolog of $S$. pombe; UNG, uracil-DNA glycosylase.
} 
$3, \mathbf{N}^{4}-\alpha$-hydroxypropano- (HPC) and crotonaldehyde to obtain $3, \mathrm{~N}^{4}-\alpha$-hydroxy- $\gamma$-methylpropano- (mHPC) adducts of cytosine. The studied adducts are alkali-labile which results in oligonucleotide strain breaks at the sites of modification upon strong base treatment. The oligonucleotides carrying adducted cytosines were studied as substrates of Escherichia coli Mug, human TDG and fission yeast Thp1p glycosylases. All the adducts studied are excised by bacterial Mug although with various efficiency: $\varepsilon$ C $>$ HEC > HPC > mHPC. The yeast enzyme excises efficiently $\varepsilon C \geq$ HEC > HPC, whereas the human enzyme excises only $\varepsilon C$. The pH-dependence curves of excision of $\varepsilon \mathrm{C}, \mathrm{HEC}$ and HPC by Mug are bell shaped and the most efficient excision of adducts occurs within the $\mathrm{pH}$ range of 8.6-9.6. The observed increase of excision of HEC and HPC above pH 7.2 can be explained by deprotonation of these adducts, which are high $\mathbf{p} K_{\mathrm{a}}$ compounds and exist in a protonated form at neutrality. On the other hand, since $\varepsilon \mathrm{C}$ is in a neutral form in the $\mathrm{pH}$ range studied, we postulate an involvement of an additional catalytic factor. We hypothesize that the enzyme structure undergoes a pH-induced rearrangement allowing the participation of Lys68 of Mug in catalysis via a hydrogen bond interaction of its $\varepsilon$-amino group with $\mathrm{N}^{4}$ of the cytosine exocyclic adducts.

Exocyclic DNA base adducts are produced by a variety of bifunctional agents of exogenous and endogenous origin. These adducts include hydroxypropano derivatives of bases formed by products of lipid peroxidation (LPO), $\alpha, \beta$-unsaturated aldehydes (enals) such as acrolein (ACR), crotonaldehyde (CRA) or trans-4-hydroxy-2-nonenal (HNE). Etheno derivatives of bases are produced by metabolites of the industrial carcinogen vinyl chloride (chloroethylene epoxide and chloroacetaldehyde (CAA)), on the other hand, they can originate endogenously from reaction of LPO products with DNA bases (reviewed by Bartsch, 1999). Any DNA damage, including exocyclic adducts, if not repaired, can lead upon cell division to mutations which, in mammals, can give rise to chronic diseases and cancer. The exocyclic adducts are of special interest since many of them are endogenously formed, most likely as a result of reaction of LPO products with DNA bases.

In the case of environmental genotoxic agents, avoidance of exposure is the most effective defense against DNA damage and its consequences. In the case of endogenous DNA damage, the repair of this damage seems to be the most important line of defense of genomic integrity. The removal of damaged bases from DNA by DNA glycosylases initiates base excision repair (BER), one of the DNA repair pathways operating in prokaryotic and eukaryotic cells. Studies on the substrate specificity of known glycosylases have revealed that some of them are active in excision of exocyclic adducts from DNA. The Escherichia coli 3-methyladenine-DNA glycosylase II (AlkA protein) excises $N^{2}, 3-\varepsilon \mathrm{G}$ (Matijasevic et al., 1992). Albeit $1, N^{6}-\varepsilon \mathrm{A}$ is a poor substrate of AlkA, its human, rat and yeast homologues remove this adduct from DNA efficiently (Singer et al.,1992; Saparbaev et al., 1995). The T/U-G mismatch specific glycosylases, $E$. coli mismatch uracil-DNA glycosylase (Mug) and human mismatch thymine-DNA glycosylase (TDG), excise $3, N^{4}-\varepsilon \mathrm{C}$ (Saparbaev \& Laval, 1998; Hang et al., 1998). Mug excises also 8-hydroxymethyl-3, $N^{4}-\varepsilon \mathrm{C}$ (Hang et al., 2002). $1, N^{2}-\varepsilon \mathrm{G}$ is excised by bacterial Mug and also by a structurally unrelated human homologue of AlkA, the ANPG protein ( $N$-alkylpurine-DNA glycosylase) (Saparbaev et al., 2002). It appears that undefined hydroxypropano-adducts are excised by AlkA (but not by ANPG) since single strand breaks are formed in plasmid DNA pretreated with ACR or CRA upon combined action of AlkA and an endonuclease (Borys \& Kuśmierek, 1998).

We present here our studies on the excision by DNA glycosylases of the simplest $3, N^{4}$-exocyclic adducts of cytosine, i.e. etheno $(\varepsilon \mathrm{C})$, hydroxyethano (HEC) and the structurally related hydroxypropano (HPC) and methyl-hy- 
droxypropano (mHPC) adducts (Fig. 1). The reaction of the cytosine moiety with CAA proceeds via an intermediate, $3, N^{4}-\alpha$-hydroxy- these adducts are generated in reaction of CAA, ACR or CRA under controlled conditions with an oligodeoxynucleotide contain-<smiles>[R]N1C=CC2=NC(O)CN2C1=O</smiles>

$3, \mathrm{~N}^{4}-\alpha$-hydroxy ethanocytosine (HEC)<smiles>[R]n1ccc2nccn2c1=O</smiles>

3, N4-etheno cytosine $(\varepsilon \mathrm{C})$<smiles>[R]N1C=CC2=NC(O)CCN2C1=O</smiles>

$3, \mathrm{~N}^{4}$ - $\alpha$-hydroxy propanocytosine (HPC)<smiles>[R]N1C=CC2=NC(O)CC(C)N2C1=O</smiles>

3,N4- $\alpha$-hydroxy- $\gamma$-methyl propanocytosine (mHPC)<smiles>O=CCCl</smiles>

chloroacetaldehyde (CAA)<smiles>C=CC=O</smiles>

acrolein (ACR)<smiles>CC=CC=O</smiles>

crotonaldehyde

(CRA)

Figure 1. Structures of adducts studied and of modifying agents.

ethanocytosine (HEC), which undergoes spontaneous dehydration to form stable $3, N^{4}-\varepsilon \mathrm{C}$ (Krzyżosiak et al.,1979). Under physiological conditions, the half life of HEC in polymers is approximately 1 day (Kuśmierek \& Singer, 1982). This time is comparable to the time of division of mammalian cells and is several fold longer than the time of division of bacterial cells. The relatively high persistence of the initially formed HEC suggests that this adduct can play an independent role in both mutagenesis and repair. 3, $N^{4}-\alpha$-hydroxypropano-deoxycytidine (HPC) is formed in reaction of deoxycytidine with ACR (Chenna \& Iden, 1993). To our knowledge the reaction of CRA with deoxycytidine as well as structures of products have never been reported, although its reaction with another deoxynucleoside, deoxyguanosine, was extensively studied and structures of adducts were published (Chung et al., 1999).

For the purpose of studies on the excision of exocyclic cytosine adducts from DNA we have elaborated an experimental method in which ing only $\mathrm{C}$ and $\mathrm{T}$ bases. The conditional inertness of $\mathrm{T}$ residues allows selective modification of $\mathrm{C}$ residues only. We used for the modification $5^{\prime}$-d(TTT TTT CTT TTT CTT TTT CTT TTT T)-3' containing three $\mathrm{C}$ residues per molecule. Although the use of oligonucleotides containing one adducted $\mathrm{C}$ would facilitate a more precise kinetic analysis of adduct excision, the enrichment of the oligonucleotide in $\mathrm{C}$ residues stabilizes the substrate DNA duplex formed by annealing the modified oligonucleotide to a complementary one, because of higher number of $\mathrm{G} \cdot \mathrm{C}$ pairs. The maintenance of a duplex structure is essential when double-strand specific DNA glycosylases such as Mug and TDG are examined. Thus, these substrates allow for a qualitative assessment rather than a precise kinetic analysis of adduct excision efficiencies by individual DNA glycosylases. Figure 2 illustrates schematically the nature of the oligonucleotide substrates and the formation of products by glycosylase/endonuclease cleavage (or by alkali treatment). 


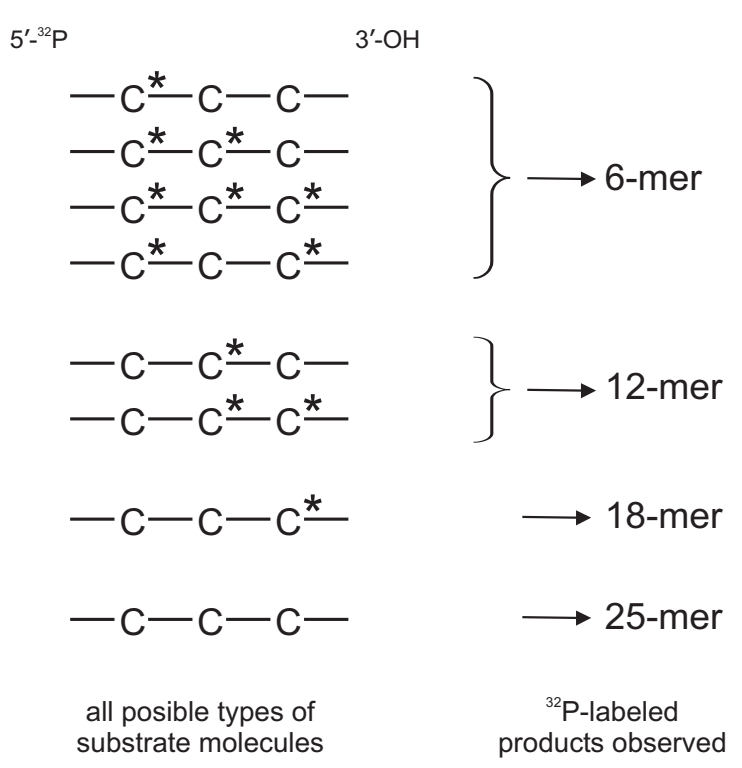

Figure 2. Schematic representation of the nature of substrate oligonucleotides and products of their cleavage.

$\mathrm{C}$ and $\mathrm{C}^{*}$ denote unmodified and modified cytosines, respectively. T-tracts are represented by solid lines. Complementary strands are omitted for clarity.

\section{MATERIALS AND METHODS}

\section{Materials}

Oligodeoxynucleotides. The 25-mer oligodeoxynucleotides, 5'-d(TTT TTT CTT TTT CTT TTT CTT TTT T)-3' (T/C 25-mer) and its complementary counterpart, and $5^{\prime}$-d(CTA GCG ACC TUUC GAC TGT CCC ACT G)-3' (U 25-mer) and its complementary counterpart containing $G$ opposite $U$, were purchased from EUROGENTEC (Herstal, Belgium). The oligonucleotides, 18-mer 5 '-d(TTT TTT CTT TTT CTT TTT)-3', 12-mer 5'-d(TTT TTT CTT TTT)-3', 6-mer 5'-d(TTT TTT)-3' and 10-mer 5'-d(CTA GCG ACC T)-3', PAGE standards for excision of modified cytosines and $U$ from the T/C 25-mer and U 25-mer, respectively, were furnished by the Oligonucleotide Synthesis Laboratory, Institute of Biochemistry and Biophysics PAS (Warsaw, Poland).

Enzymes. The DNA fragment containing the $m u g$ gene of $E$. coli was obtained by PCR amplification using $E$. coli wild type genomic DNA with the following oligonucleotide primers derived from $5^{\prime}$ and $3^{\prime}$ regions on the map of $E$. coli K12 (Genbank entry U28379): P1936, 5'-d(CCT GGT GGA TCC GTC AGG CGA TCA CCC)-3'; P21907, 5'-d(GCG ACT GCT CCT GCA GAA AAT CCA GCG)-3'. The PCR DNA fragment was digested with BamHI and PstI and then was inserted in the BamHI-PstI sites of the pUC19 vector and verified by sequencing. The resulting recombinant plasmid peCDG19 was used to overexpress the Mug protein in E. coli strain JM105. Purification of the Mug protein was performed as described elsewhere (Saparbaev \& Laval, 1998). The human hTDG and the fission yeast (Schizosaccharomyces pombe) Thp1p glycosylases were prepared as described before (Hardeland et al., 2000; 2003). AlkA glycosylase was purified from $E$. coli strain JM105 harboring pAlk10 plasmid containing the alkA gene using the modified procedure described in (Tudek et al., 1998). Nth protein was provided by Dr. Barbara Tudek of our Institute. T4 polynucleotide kinase was from TaKaRa (Japan), bacterial alkaline phosphatase was from Sigma, snake venom phosphodiesterase and P1 nuclease from Pharmacia.

Other materials. Chloroacetaldehyde (45\% aq. solution) and acrolein were Merck products, crotonaldehyde (cis and trans isomers, approx. 1:25) was from Fluka, $\left[\gamma_{-}^{32}\right.$ P]ATP (3000 Ci/mmol) from Amersham.

\section{Chromatography}

HPLC was performed using a Waters dual pump system with a tunable UV/visible light absorbance detector managed by Millenium 2010SS (version 2.15) controller. All separations were performed on a Waters Nova-Pak ${ }^{\circledR}$ C18 $60 \AA 4 \mu \mathrm{m} 4.6 \times 250 \mathrm{~mm}$ cartridge column using a linear gradient of $20 \mathrm{mM}$ ammonium formate ( $\mathrm{pH} 6-$ system I or adjusted to pH 9 with conc. ammonia - system II) $\times 30 \%$ aq. $\mathrm{MeOH}$ over $30 \mathrm{~min}$ at a flow rate of 1 
$\mathrm{ml} / \mathrm{min}$. Relevant retention times are given in Table 1. For thin-layer chromatography (TLC) silica gel $60 \mathrm{~F}_{254}$ aluminum sheets (Merck, catalog No. 1.05554) were used and the following solvents: A - 2-propanol/10 mM Tris/HCl buffer pH 8.0 (9:1, by vol.) and B chloroform/methanol $(8: 2$, by $\mathrm{v} / \mathrm{v})$. matography and elution. The eluate of HEdC was kept frozen at $-20^{\circ} \mathrm{C}$.

Reaction of deoxycytidine with ACR formation of HPdC. To a solution of $2 \mathrm{mg}$ of deoxycytidine (approx. $0.008 \mathrm{mmol}$ ) in $100 \mu \mathrm{l}$ of $0.5 \mathrm{M}$ Na-phosphate buffer $\mathrm{pH} 7.0$ or in 100 $\mu \mathrm{l}$ of $0.5 \mathrm{M}$ Na-acetate buffer, $\mathrm{pH} 4.5,2 \mu \mathrm{l}$ of

Table 1. HPLC retention times of relevant compounds

\begin{tabular}{ccc}
\hline \multirow{2}{*}{ Compound } & \multicolumn{2}{c}{ Retention time (min) } \\
\cline { 2 - 3 } & system I (pH 6) & system II (pH 9) \\
\hline $2^{\prime}$-deoxythymidine & 14.8 & 15.7 \\
$2^{\prime}$-deoxycytidine & 8.7 & 9.7 \\
HEdC & 10.0 & 13.5 \\
$\varepsilon$ dC & 21.6 & 23.5 \\
HPdC & 16.0 & 17.4 \\
mHPdC & 15.3 and 16.3 & 20.4 and 21.2 \\
\hline
\end{tabular}

\section{Reaction of deoxynucleosides with CAA,} ACR and CRA

Reaction of deoxycytidine with CAA formation of HEdC and $\varepsilon d C$. To a solution of $2.5 \mathrm{mg}$ of deoxycytidine (approx. 0.01 mmol) in $100 \mu \mathrm{l}$ of $0.5 \mathrm{M}$ Na-phosphate buffer, pH 7.0, was added $20 \mu \mathrm{l}$ of $45 \%$ aq. solution of CAA (approx. $0.14 \mathrm{mmol}$ ). Since the $\mathrm{pH}$ of the mixture dropped after addition of $\mathrm{CAA}, 10 \mu \mathrm{l}$ of $2 \mathrm{M} \mathrm{NaOH}$ was added to bring the $\mathrm{pH}$ to about 7 . The mixture was incubated at $37^{\circ} \mathrm{C}$ and monitored by HPLC in solvent system II and by TLC in solvent $\mathrm{A}\left(R_{\mathrm{F}}=0.29\right.$, 0.47 and 0.60 for $\mathrm{HEdC}, \mathrm{dC}$ and $\varepsilon \mathrm{dC}$, respectively). After $3 \mathrm{~h}$ of incubation the mixture (approx. $70 \%$ of $\mathrm{HEdC}$, approx. $25 \%$ of $\varepsilon \mathrm{dC}$ and approx. $5 \%$ of dC) was separated by TLC. Bands corresponding to HEdC were eluted using $10 \mathrm{mM}$ ammonium formate adjusted to pH 9 by concentrated ammonia, whereas those corresponding to $\varepsilon \mathrm{dC}$, using methanol. HPLC analysis of the HEdC eluate revealed the presence of less than $5 \%$ of $\varepsilon \mathrm{dC}$ which was formed by dehydration of HEdC during chro-
ACR (approx. $0.03 \mathrm{mmol}$ ) was added and mixtures were incubated at $37^{\circ} \mathrm{C}$. The mixtures were analyzed by HPLC in solvent system I. At $\mathrm{pH} 4.5$ single product (HPdC) was formed, whereas at $\mathrm{pH} 7.0$ the formation of two additional minor products (retention times 15.5 min and $18.1 \mathrm{~min}$ ) was observed. The products of the reaction at $\mathrm{pH} 4.5$ after $24 \mathrm{~h}$ of incubation were separated by TLC in solvent B $\left(R_{\mathrm{F}}=0.05\right.$ and 0.12 for $\mathrm{HPdC}$ and $\mathrm{dC}$, respectively) and bands were eluted with methanol. UV data of HPdC $\left(\lambda_{\max }, \mathrm{nm}\right): \mathrm{pH} 4.5-216$, 282 ; pH $7.1-217,282$ (spectrum virtually identical with that at $\mathrm{pH} 4.5$ ); $\mathrm{pH} 12-230$, $271 ; \mathrm{p} K_{\mathrm{a}}=8.6$ (determined spectrophotometrically).

Reaction of deoxycytidine with CRA formation of $\mathbf{m H P d C}$. To a solution of $2 \mathrm{mg}$ of deoxycytidine (approx. $0.008 \mathrm{mmol}$ ) in 100 $\mu \mathrm{l}$ of $0.5 \mathrm{M} \mathrm{Na}$-acetate buffer, $\mathrm{pH} 4.5,2.5 \mu \mathrm{l}$ of CRA (approx. $0.03 \mathrm{mmol}$ ) was added and mixture was incubated at $37^{\circ} \mathrm{C}$. HPLC in solvent system I shows slow formation of product in the form of a double peak. Products were separated by TLC in solvent $\mathrm{B}\left(R_{\mathrm{F}}=0.07\right.$ and 
0.12 for $\mathrm{mHPdC}$ and $\mathrm{dC}$, respectively). UV data of mHPdC $\left(\lambda_{\max }, \mathrm{nm}\right): \mathrm{pH} 3-283 ; \mathrm{pH}$ $6.5-283$ (spectrum virtually identical with that at $\mathrm{pH} 3) ; \mathrm{pH} 12-229,271$. UV data indicate $\mathrm{p} K_{\mathrm{a}}>7$.

Reaction of thymidine with ACR and $\boldsymbol{C R} \boldsymbol{A}$. Thymidine (2 $\mathrm{mg}$, approx. $0.008 \mathrm{mmol}$ ) in $100 \mu \mathrm{l}$ of $0.5 \mathrm{M}$ buffer was reacted with ACR ( $2 \mu$ l, approx. $0.03 \mathrm{mmol}$ ) in Na-phosphate $\mathrm{pH} 7.0$ or Na-acetate $\mathrm{pH} 4.5$, and with CRA (2.5 $\mu$ l, approx. $0.03 \mathrm{mmol})$ in Na-acetate $\mathrm{pH} 4.5$ at $37^{\circ} \mathrm{C}$. HPLC analysis (solvent system I) of reactions of ACR ( $24 \mathrm{~h})$ and CRA (7 days) at $\mathrm{pH} 4.5$ reveals absence of any product at the level of detection $0.1 \%$. ACR reaction at $\mathrm{pH} 7$ shows after $24 \mathrm{~h}$ formation of two products in $5 \%$ and $50 \%$ yield (retention times $16.5 \mathrm{~min}$ and $24.0 \mathrm{~min}$, respectively).

\section{Modification of T/C 25-mer with CAA, ACR and CRA and analysis of products}

Reaction with CAA. To a solution of 10 nmol of the T/C 25-mer in $100 \mu \mathrm{l}$ of $1 \mathrm{M}$ Na-cacodylate buffer, $\mathrm{pH} 9.0,5 \mu \mathrm{l}$ of CAA (approx. $35 \mu \mathrm{mol}$ ) was added, and the mixture was incubated at $37^{\circ} \mathrm{C}$. Samples $(20 \mu \mathrm{l})$ were taken at various times of reaction, the oligonucleotide was ethanol precipitated (3 volumes, in the presence of $0.3 \mathrm{M} \mathrm{Na-acetate}$ $\mathrm{pH} 5.2$ and $10 \mathrm{mM} \mathrm{MgCl}_{2}$ ), redissolved in TE buffer, aliquots were enzymatically hydrolysed to deoxynucleosides (see below) and then HPLC analysed. Results of analyses are shown in Table 2. In order to achieve complete conversion of $\mathrm{HEC}$ to $\varepsilon \mathrm{C}$, samples of CAA-modified oligonucleotide in TE buffer were brought to $\mathrm{pH} 6.5$ by addition of $0.8 \mathrm{M}$ Na-cacodylate buffer $\mathrm{pH} 6.5$ to the final concentration $20 \mathrm{mM}$ and incubated at $37^{\circ} \mathrm{C}$ for $72 \mathrm{~h}$.

Reaction with ACR. To a solution of 30 nmol of the T/C 25-mer in $100 \mu \mathrm{l}$ of $0.5 \mathrm{M}$ Na-acetate buffer, $\mathrm{pH} 4.5,10 \mu \mathrm{l}$ of ACR (approx. $150 \mu \mathrm{mol}$ ) was added, and the mixture was incubated at $37^{\circ} \mathrm{C}$. Samples $(50 \mu \mathrm{l})$ were taken after 0.5 and $1 \mathrm{~h}$ of incubation and then they were worked-up as samples from CAA reaction. HPLC analysis revealed that after $0.5 \mathrm{~h}$ approx. $40 \%$, whereas after $1 \mathrm{~h}$ approx. $50 \%$ of $\mathrm{C}$ residues in the oligonucleotide were modified, as estimated on the basis of the peak areas in HPLC.

Reaction with CRA. To a solution of 15 $\mathrm{nmol}$ of the T/C 25-mer in $100 \mu \mathrm{l}$ of $0.5 \mathrm{M}$ Na-acetate buffer, $\mathrm{pH} 4.5,12 \mu \mathrm{l}$ of CRA (approx. $140 \mu \mathrm{mol}$ ) was added, and the mixture was incubated at $37^{\circ} \mathrm{C}$. Samples $(30 \mu \mathrm{l})$ were taken after 2,3 and 5 days and after work-up (see above) were HPLC analysed. After 5 days of reaction approx. $20 \%$ of $\mathrm{C}$ residues in the oligonucleotide were modified, as estimated on the basis of the peak areas in HPLC.

Enzymatic hydrolysis of modified oligonucleotides. Typical sample contained 1-2 nmol of modified oligonucleotide in $50 \mu \mathrm{l}$ of $50 \mathrm{mM}$ Tris/HCl buffer $\mathrm{pH} 8.5$ and $5 \mathrm{mM}$ $\mathrm{MgCl}_{2}$. Bacterial alkaline phosphatase, snake venom phosphodiesterase and $\mathrm{P} 1$ nuclease were added ( 0.5 unit of each enzyme), the mixture was incubated at $37^{\circ} \mathrm{C}$ for $3-6 \mathrm{~h}$ and then HPLC analysed.

\section{Adduct excision assay}

The following preparations of modified T/C 25-mer were used for study of excision of particular adducts: (i) HEC - CAA modified $0.5 \mathrm{~h}$, approx. $30 \%$ of $\mathrm{C}$ residues modified, ratio HEC : $\varepsilon \mathrm{C}$ was $94: 6$ at time of HPLC analysis; (ii) $\varepsilon \mathrm{C}-$ (i) incubated $72 \mathrm{~h}\left(\mathrm{pH} 6.5,37^{\circ} \mathrm{C}\right)$ for complete conversion of HEC into $\varepsilon \mathrm{C}$; (iii) HPC - ACR modified $1 \mathrm{~h}$, approx. $50 \%$ of $\mathrm{C}$ residues modified and (iv) $\mathrm{mHPC}-\mathrm{CRA}$ modified 5 days, approx. $20 \%$ of $\mathrm{C}$ residues modified.

5'-Labeling and annealing. To $50 \mathrm{pmol}$ of oligonucleotide in $50 \mathrm{mM}$ Tris/ $\mathrm{HCl} \mathrm{pH}$ 8.0, 10 $\mathrm{mM} \mathrm{MgCl}_{2}$ and $5 \mathrm{mM}$ dithiothreitol, 25-50 $\mu \mathrm{Ci}\left[\gamma_{-}{ }^{32} \mathrm{P}\right] \mathrm{ATP}$ and 10 units of $\mathrm{T} 4$ kinase were added (final volume $20 \mu \mathrm{l}$ ), and the mixture was incubated at $37^{\circ} \mathrm{C}$ for $30 \mathrm{~min}$. The ${ }^{32}$ P-labeled oligonucleotide was ethanol pre- 
cipitated and redissolved in $40 \mu \mathrm{l}$ of $\mathrm{TE}$ buffer. The complementary oligonucleotide in a double molar excess and $5 \mu \mathrm{l}$ of $1 \mathrm{M} \mathrm{NaCl}$ were added (final volume $50 \mu \mathrm{l}$ ), the mixture was placed in an $80^{\circ} \mathrm{C}$ water bath and allowed to cool to room temperature (about $1.5 \mathrm{~h}$ ). After that, $50 \mu \mathrm{l}$ of TE buffer was added and the sample frozen at $-20^{\circ} \mathrm{C}$. The final solution contained $0.5 \mathrm{pmol} / \mu \mathrm{l}$ of ${ }^{32} \mathrm{P}$-labeled and annealed oligonucleotide in $50 \mathrm{mM} \mathrm{NaCl} / \mathrm{TE}$ buffer solution.

Glycosylase/endonuclease reaction. To $16 \mu \mathrm{l}$ of reaction buffer $(50 \mathrm{mM}$ Tris $/ \mathrm{HCl}, \mathrm{pH}$ given in figure legends, $50 \mathrm{mM} \mathrm{NaCl}, 1 \mathrm{mM}$ EDTA, $5 \mathrm{mM}$ mercaptoethanol) $4 \mu \mathrm{l}$ (2 pmol) of oligonucleotide and $2 \mu \mathrm{l}$ of tested glycosylase (names and amounts given in figure legends) were added. Unless indicated otherwise, samples were incubated at $30^{\circ} \mathrm{C}$ for 30 min, and then ice-chilled. To the chilled samples $2 \mu \mathrm{l}$ of $1 \mathrm{M} \mathrm{KCl}$ and $2 \mu \mathrm{l}(20 \mathrm{ng}$ ) of Nth protein were added, the mixtures were incubated at $30^{\circ} \mathrm{C}$ for $30 \mathrm{~min}$ and then ice-chilled again. Finally, $2.6 \mu \mathrm{l}$ of proteinase $\mathrm{K}$ reaction buffer (0.5 M Tris/ $\mathrm{HCl} \mathrm{pH} \mathrm{8.0,} 50 \mathrm{mM} \mathrm{CaCl}_{2}$ ) and $2 \mu \mathrm{l}(2 \mu \mathrm{g})$ of proteinase $\mathrm{K}$ was added and samples were incubated at $55^{\circ} \mathrm{C}$ for $30 \mathrm{~min}$. Reaction was terminated by addition of $20 \mu \mathrm{l}$ of denaturating buffer (formamide/0.5 M Na-EDTA, 95:5, v/v; 0.05\% bromophenol dye).

$\mathrm{NaOH}$ treatment of modified oligonucleotides. To a solution of 2 pmol of oligonucleotide in $25 \mu \mathrm{l}$ of water $5 \mu \mathrm{l}$ of $1 \mathrm{M}$ $\mathrm{NaOH}$ was added and then the mixture was incubated at $75^{\circ} \mathrm{C}$ for $30 \mathrm{~min}$. After cooling, $20 \mu \mathrm{l}$ of denaturating buffer was added.

PAGE electrophoresis. Samples after glycosylase/endonuclase reaction or after $\mathrm{NaOH}$ treatment were denaturated at $80-90^{\circ} \mathrm{C}$ for $5 \mathrm{~min}$ and then ice-chilled for another $5 \mathrm{~min}$. Aliquots of $5-10 \mu \mathrm{l}$ were loaded on $20 \%$ polyacrylamide gel $(160 \times 160 \times 1.5 \mathrm{~mm})$ prepared in $8 \mathrm{M}$ urea and TBE buffer, and electrophoresed at $300-500 \mathrm{~V}(20 \mathrm{~mA})$ in TBE buffer at room temperature for 3-5 h until the bromophenol dye has run about $75 \%$ of the length of the gel.
Gel analysis. Gels after electrophoresis were wrapped in food foil, placed in a phosphoimager cassette and exposed for 4-18 h at $4^{\circ} \mathrm{C}$. The cassette screen was scanned using a Molecular Dynamics Storm 820 apparatus and scans were analyzed using the Storm Scanner Image Quant 5.2 and Image Tools computer programs.

\section{RESULTS}

Chemistry of adducts formation. Preparation of oligodeoxynucleotide substrates to study excision of $\varepsilon \mathrm{C}$, HEC, HPC and mHPC

\section{CAA adducts}

The reaction of $\mathrm{dC}$ with $\mathrm{CAA}$ at $\mathrm{pH}$ approx. 7 leads to formation of $\mathrm{HEdC}$ and $\varepsilon \mathrm{dC}$ in proportion approx. 3:1 (see Fig. 1 for structures). The neutral $\mathrm{pH}$ was chosen for this reaction since dehydration of the initially formed HEdC to $\varepsilon \mathrm{dC}$ proceeds much faster in acidic than in neutral and moderately basic solutions (Kuśmierek \& Singer, 1982). This procedure allowed us to prepare both dC-CAA adducts, which were identified on the basis of UV spectra (Barrio et al., 1972; Krzyżosiak et al., 1979).

In order to obtain the highest proportion of HEC in the T/C 25-mer, the reaction of the oligonucleotide with CAA was carried out at $\mathrm{pH}$ 9. HPLC analysis of an enzymatic hydrolysate of the T/C 25-mer reacted with CAA for $0.5 \mathrm{~h}$ revealed that $29 \%$ of $\mathrm{C}$ residues were modified and the ratio of HEC: $\varepsilon \mathrm{C}$ was $94: 6$. Extending the time of reaction leads to higher level of modification, however, the ratio of HEC : $\varepsilon \mathrm{C}$ changes simultaneously in favor of dehydrated adduct (Table 2). Therefore, the preparation of the T/C 25-mer modified for $0.5 \mathrm{~h}$ was chosen as the substrate to study the excision of HEC. In order to avoid the increase of proportion of $\varepsilon \mathrm{C}$, the modified 
Table 2. Reactivity of cytosine residues in 5'-d(TTT TTT CTT TTT CTT TTT CTT TTT T)-3' oligonucleotide (T/C 25-mer) treated with chloroacetaldehyde (CAA) ${ }^{a}$

\begin{tabular}{|c|c|c|c|c|c|}
\hline \multirow[t]{2}{*}{ Reaction time (h) } & \multicolumn{3}{|c|}{$\%$ of deoxynucleoside ${ }^{b}$} & \multicolumn{2}{|r|}{$\%$ of $\mathrm{C}$} \\
\hline & $\mathrm{dT}$ & $\mathrm{dC}$ & HEdC & $\varepsilon \mathrm{dC}$ & modification \\
\hline 0 & 88.1 & 11.9 & 0.0 & 0.0 & 0 \\
\hline 0.5 & 88.2 & 8.4 & 3.2 & 0.2 & 29 \\
\hline 1.0 & 88.2 & 6.6 & 4.5 & 0.7 & 44 \\
\hline 2.0 & 88.7 & 4.5 & 5.2 & 1.6 & 60 \\
\hline 4.0 & 90.1 & 2.8 & 3.7 & 3.4 & 72 \\
\hline
\end{tabular}

\footnotetext{
${ }^{a}$ See Methods for conditions of reaction. ${ }^{b}$ Determined by HPLC in solvent system II of enzymatic hydrolyzates on the basis of peak areas and molar absorption coefficients at $280 \mathrm{~nm}$ at $\mathrm{pH} 9\left(\mathrm{dT}-5.8 \times 10^{3}, \mathrm{dC}-6.8 \times 10^{3}, \mathrm{HEdC}-7.1 \times 10^{3}, \varepsilon \mathrm{dC}-\right.$ $9.3 \times 10^{3}$ ). The theoretical ratio of $\mathrm{dC}$ (or sum of $\mathrm{dC}$ and CAA-modified $\mathrm{dC}$ ): $\mathrm{dT}$ is $12: 88$.
}

oligonucleotide was stored at $-20^{\circ} \mathrm{C}$ and all handling (with the exception of annealing and enzymatic reactions) was in an ice-bath. The procedure most deleterious for HEC stability, that of annealing (placement in an $80^{\circ} \mathrm{C}$ bath and $1.5 \mathrm{~h}$ cooling to room temperature) causes transformation of $20 \%$ of HEC into $\varepsilon \mathrm{C}$. All together, we estimate the proportion HEC: $\varepsilon \mathrm{C}$ to be approx. $9: 1$ at the time of glycosylase reaction. Transformation of HEC in the reacted $\mathrm{T} / \mathrm{C} 25$-mer into $\varepsilon \mathrm{C}$ was achieved by prolonged incubation at $\mathrm{pH}$ 6.5. HPLC analysis of an enzymatic hydrolysate showed that approx. $99 \%$ of the adduct was in the form of $\varepsilon \mathrm{C}$.

ACR and CRA adducts

At $\mathrm{pH}$ 4.5 ACR and CRA react with $\mathrm{dC}$ forming single adducts, however, ACR is much more reactive than CRA. HPLC analyses show that with ACR approx. $80 \%$ of $\mathrm{dC}$ is transformed into adduct during $24 \mathrm{~h}$, whereas with CRA only approx. $20 \%$ during a 7 day reaction. The dC-CRA adduct appears in the HPLC profile in the from of a double peak. The double peak is also seen in the HPLC profile of the adduct purified by TLC.

The reaction of $\mathrm{dC}$ with $\mathrm{ACR}$ at $\mathrm{pH} 7$ gives three products with the most abundant prod- uct showing retention time identical to $\mathrm{HPdC}$, whereas that of $\mathrm{dT}$ at $\mathrm{pH} 7$ gives two products. The products formed at $\mathrm{pH} 7$ were not investigated further. On the other hand, HPLC analysis of the reaction of dT at $\mathrm{pH} 4.5$ with ACR (1 day) or with CRA (7 days) reveals an absence of any product at the level of detection, $0.1 \%$ (not shown).

Because $\mathrm{dT}$ is virtually inert and $\mathrm{dC}$ gives a single adduct in reaction with ACR or CRA at $\mathrm{pH} 4.5$, we used these conditions for selective modification of $\mathrm{C}$ residues in the $\mathrm{T} / \mathrm{C} 25$-mer. The reaction of the T/C 25-mer with a large excess of ACR proceeds fast to give approx. $50 \%$ of modification of $\mathrm{C}$ residues after $1 \mathrm{~h}$. The less reactive CRA under analogous conditions gives only approx. $20 \%$ of modification after 5 days of reaction. The prolonged treatment causes formation of an elevated level of chain breaks and Nth sensitive sites in CRA treated oligonucleotide (Fig. 4). Since the molar absorption coefficients of $\mathrm{HPdC}$ and $\mathrm{mHPdC}$ are not known, only an approximate level of modification was calculated on the basis of comparison of peak areas in HPLC profiles. Another estimation of the level of adducts was done on the basis of results of alkaline cleavage of modified oligonucleotides (see below). Assuming that alkaline cleavage occurs at each modified cytosine and that dis- 
tribution of adducts along the oligonucleotide chain is similar for the adducts produced by CAA, ACR and CRA, we can expect that the same percentage of cleavage corresponds to the same level of modification. Since the percentage of alkaline cleavage for CAA- and ACR-modified oligonucleotide is identical (64\%, Fig. 4), the level of modification of $\mathrm{C}$ residues by ACR should be equal to that by CAA, thus approx. 30\%. The level of modification by CRA is lower, as indicated by alkaline cleavage (51\%, Fig. 4) and HPLC analysis (approx. 20\%).

\section{Alkaline lability of cytosine adducts}

We have found that alkaline treatment $(0.17$ $\mathrm{M} \mathrm{NaOH}, 75^{\circ} \mathrm{C}, 30 \mathrm{~min}$ ) of oligonucleotides containing $\varepsilon \mathrm{C}$, HEC, HPC or mHPC produces strain breaks at the site of modification. This is visualized in Fig. 3 where the cleavage of ACR-treated C/T 25-mer containing HPC is shown. Figure 4 contains summarized data on alkaline cleavage of all four modified T/C 25 -mers studied. Since a $20 \mathrm{~min}$ treatment gives essentially the same quantitative results as a 30 min treatment, we assume that cleavage occurs at each modified cytosine under conditions applied.

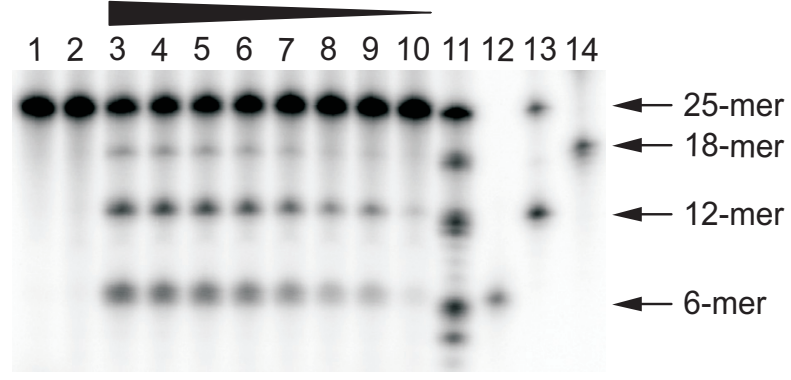

Figure 3. Excision of HPC by $E$. coli Mug at pH 8.6 from 5 '-d(TTT TTT CTT TTT CTT TTT CTT TTT T)-3' oligonucleotide reacted with acrolein.

Lane 1: control (buffer only); lane 2: Nth (20 ng); lanes 3-10, Mug 0.07, 0.14, 0.28, 0.56, 1.1, 2.3, 4.5 and 11.3 pmols, respectively, and $\mathrm{Nth}(20 \mathrm{ng})$ in each assay; lane 11: $\mathrm{NaOH}$ added and sample heated at $75^{\circ} \mathrm{C}$ for 30 min; lanes 12-14: oligonucleotide markers.
We did not study and we do not propose the mechanism of this reaction. Nevertheless, HPLC analysis of $\varepsilon \mathrm{dC}$ incubated at $\mathrm{pH} 12$ has revealed formation of several interconverting products to give essentially one final product lacking deoxyribose (not shown). This indicates that at least in the case of $\varepsilon \mathrm{dC}$, a series of rearrangements leads to depyrimidination and in consequence to formation of abasic site which is cleaved by alkali. A similar rearrangement (although less complex) leading to the formation of an abasic site was reported for $\varepsilon \mathrm{dA}$ and oligonucleotides containing $\varepsilon \mathrm{A}$ (Speina et al., 2001).

\section{Excision of cytosine exocyclic adducts by bacterial Mug}

All four adducts tested were excised by the bacterial enzyme although with various efficiency $(\varepsilon \mathrm{C}>\mathrm{HEC}>\mathrm{HPC}>\mathrm{mHPC}$, Fig. 4$)$. Excision assays were performed at $\mathrm{pH} 8.6$ be-

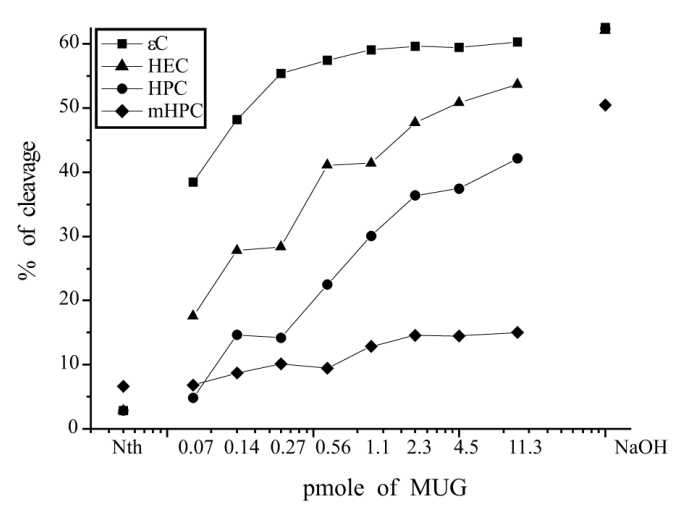

Figure 4. Comparison of excision of $\varepsilon \mathrm{C}$, HEC, HPC and mHPC by $E$. coli Mug at pH 8.6 - the enzyme concentration-dependent generation of Nth-sensitive AP-sites.

Data for excision of HPC are from the experiment visualized by gel autoradiograph presented in Fig. 3. Data for excision of other adducts are from analogous experiments (not shown). The ordinate (\% of cleavage) represents percentage of products formed in assay (sum of 18-mer, 12-mer and 6-mer) related to the sum of substrate and products as determined on the basis of phosphoimager analysis of gel autoradiographs. Controls (not shown): $3 \%$ and 1-2\%, Nth: $7 \%$ and $2-3 \%, \mathrm{NaOH}: 51 \%$ and $64 \%$, for $\mathrm{mHPC}$ and for other adducts, respectively. 
cause at this $\mathrm{pH}$ a plateau in $\mathrm{pH}$-dependence of excision started (Fig. 5, see next paragraph). The gel autoradiograph presented in Fig. 3 shows the excision of HPC as an exemplary illustration of excision of all studied adducts from modified T/C 25-mers. High excision of $\varepsilon \mathrm{C}$ was observed at the lowest ratio of the enzyme to the modified T/C 25-mer (approx. 1:30), a plateau was reached at the ratio approx. $1: 2$ at the level of $58-60 \%$ of cleavage, which corresponds to practically complete excision of all ethenocytosines as estimated on the basis of alkaline treatment which results in $64 \%$ of cleavage. The excision of HEC and HPC is less efficient than excision of $\varepsilon \mathrm{C}$ and does not reach a plateau within the enzyme concentration range studied. mHPC is the worst substrate among those studied.

\section{Comparison of excision of $\varepsilon \mathrm{C}$, HEC, HPC and uracil by Mug at various $\mathrm{pH}$}

We found that excision of the studied adducts is more efficient at $\mathrm{pH}$ values higher than the $\mathrm{pH}$ range 7.2-8.0, which is most often employed by various investigators. Because of that, and also because the $\mathrm{p} K_{\mathrm{a}}$ values of the studied adducts are different, we have undertaken studies on the $\mathrm{pH}$ dependence of the adducts' excision. The $\mathrm{pH}$-dependence of the efficiency of excision of $\varepsilon \mathrm{C}$, HEC, HPC and $U$ is shown in Fig. 5. The excision of $U$ shows some tendency to increasing with increasing $\mathrm{pH}$ within the range 7.2-9.6. The $\mathrm{pH}$-dependence curves for excision of $\varepsilon \mathrm{C}$, HEC and HPC are bell-shaped with the maximum efficiency of excision between $\mathrm{pH} 8.6$ and $\mathrm{pH} 9.6$.

\section{Excision of cytosine exocyclic adducts by eukaryotic Thp1p and hTDG}

Several experiments on the $\mathrm{pH}$ dependency with fission yeast Thp1p and human TDG showed that excision of adducts was more efficient at $\mathrm{pH} 8.6$ than at lower $\mathrm{pH}$. Therefore,

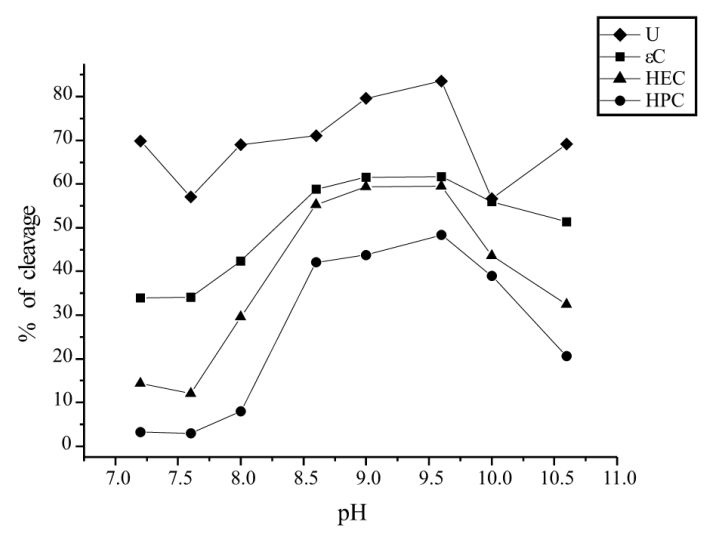

Figure 5. Excision of $\varepsilon$, HEC, HPC and uracil (U) by $E$. coli Mug - pH dependence.

Excision of uracil was studied using $5^{\prime}$-d(CTA GCG ACC TUC GAC TGT CCC ACT G)-3' (U 25-mer) as substrate. In each assay 2 pmols of oligonucleotide was incubated with $2.3 \mathrm{pmol}$ of Mug, followed by addition of $20 \mathrm{ng}$ of Nth. For explanations see legend to Fig. 4. Each point in graph represents an average value of 1-8 independent determinations (for cytosine adducts in $\mathrm{pH}$ range $7.2-9.0$ of $3-8$ determinations).
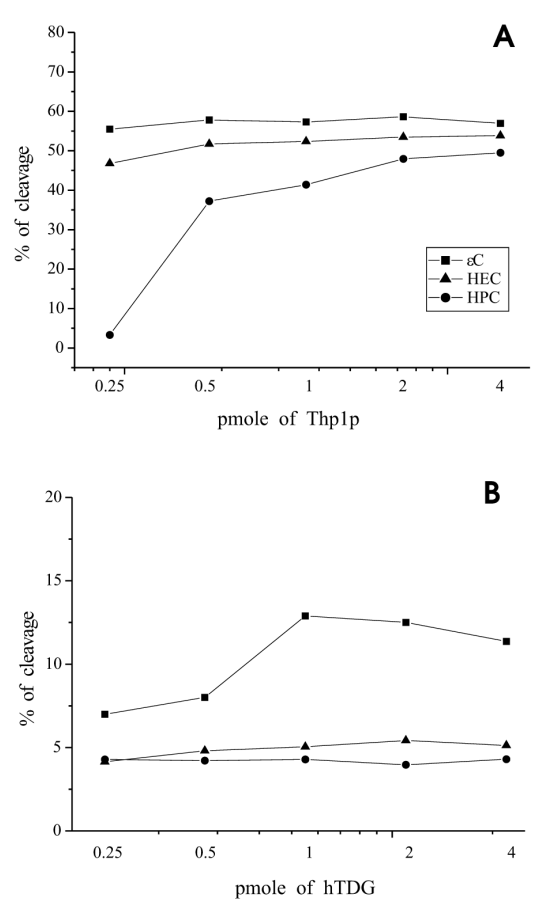

Figure 6. Comparison of excision of $\varepsilon \mathrm{C}, \mathrm{HEC}$ and HPC by Thp1p (A) and hTDG (B) - the enzyme concentration-dependent generation of Nth-sensitive AP-sites.

In each assay 2 pmols of modified T/C 25-mer was incubated for $60 \mathrm{~min}$ at $30^{\circ} \mathrm{C}$ at $\mathrm{pH} 8.6$ with 4 pmols of glycosylase, followed by addition of $20 \mathrm{ng}$ of Nth. Cleavage of untreated and Nth-treated oligonucleotides was $1-2 \%$ and $2-3 \%$, respectively. 
all the experiments presented here with the eukaryotic enzymes were performed at $\mathrm{pH}$ 8.6. The enzyme concentration dependence of the excision of $\varepsilon \mathrm{C}, \mathrm{HEC}$ and $\mathrm{HPC}$ is presented in Fig. 6 for both glycosylases. At the highest enzyme/substrate ratio $(2: 1)$ the excision of the three adducts by $\mathrm{Thp} 1 \mathrm{p}$ proceeds with high efficiency (Fig. 6A) whereas hTDG is completely inactive in excision of HEC and HPC and shows only weak activity in excision of $\varepsilon \mathrm{C}$ (Fig. 6B).

\section{DISCUSSION}

Preparation of oligodeoxynucleotides bearing exocyclic cytosine adducts by reaction with modifying agents

It is known that thymine is the least reactive among the DNA bases in general. Thymidine and uridine do not react with chloroacetaldehyde (CAA), in contrast to cytidine, adenosine and guanosine, the nucleosides bearing exocyclic amino groups (Leonard, 1984). The reactions of deoxyguanosine with ACR, CRA and HNE, and the structures of adducts, were studied extensively (Chung et al., 1999), however, studies dealing with reaction of other nucleosides and univocal determination of the structure of products are very rare. Our recent studies have shown that all four DNA bases are targets for HNE revealing different reactivity: $\mathrm{dG}>\mathrm{dC}>\mathrm{dA} \approx \mathrm{dT}$, however, the detailed structures of these adducts (except dG; Chung et al., 1999) have not been solved yet (Kowalczyk et al., 2004). Studies on the reaction of thymidine and 2 '-deoxyuridine revealed that these nucleosides form with ACR N3-(3"'-oxopropyl) adducts in neutral or alkaline conditions ( $\mathrm{pH}$ 9.2), but they remain unreactive in acidic solution, in contrast to 2 -deoxycytidine which at $\mathrm{pH} 4.2$ reacts efficiently to give $3, N^{4}-\alpha$-hydroxypropano- 2 '-deoxycytidine (HPdC, Fig. 1) (Chenna et al., 1992; Chenna \& Iden, 1993). 2'-Deoxyadeno- sine reacted with ACR gives $1, \mathrm{~N}^{6}$ - $\alpha$-hydroxypropano adduct (Smith et al.,1990).

In our studies we took advantage of the existing knowledge on the reactivity of deoxycytidine and on properties of its CAA (Barrio et al., 1972; Krzyżosiak et al., 1979; Kuśmierek \& Singer, 1982) and ACR adduct (Chenna \& Iden, 1993). Since, to our knowledge, the reaction of CRA with deoxycytidine as well as the structure of the adduct have never been studied, we propose the structure of $3, N^{4}-\alpha$-hydroxy- $\gamma$-methylpropano- $2^{\prime}$-deoxycytidine (mHPdC, Fig. 1) for the dC-CRA adduct by analogy to the structure of the dC-ACR adduct. Both adducts show virtually identical UV spectra which are in conformity with the spectra reported for HPdC (Chenna $\&$ Iden, 1993), and both adducts are high $\mathrm{p} K_{\mathrm{a}}$ compounds. The dC-CRA adduct appears in the HPLC profile in the from of a double peak (Table 1), which very likely represents a pair of diastereoisomers, because of the presence of two chiral carbon atoms in the $3, \mathrm{~N}^{4}-\alpha$-hydroxy- $\gamma$-methylpropano bridge. Similar double peaks were observed in HPLC profiles of dG-CRA adducts and this was accounted for by separation of diastereoisomers (Chung et al., 1999).

The reaction conditions elaborated in studies on reactions of deoxycytidine and thymidine allowed us to achieve selective modification of cytosine residues in the $5^{\prime}$-d(TTT TTT CTT TTT CTT TTT CTT TTT T)-3' oligonucleotide. The selectivity of modification was confirmed by HPLC analyses of oligonucleotides hydrolyzed to deoxynucleosides as well as by cleavage of the oligonucleotides at the site of modification by combined MUG-type glycosylase and endonuclease action or by alkali treatment.

\section{Excision of cytosine exocyclic adducts by DNA glycosylases}

The hydrolytic deamination of cytosine (or 5-methylcytosine) to uracil (or thymine) is one of the most frequent forms of endogenous 
DNA damage (Lindahl, 1993). The U.G (or T.G) mismatches, if unrepaired, result in transition mutations. All organisms have evolved DNA repair glycosylases that remove these deaminated bases. Uracil-DNA glycosylases (UDGs) have similar structural motifs and similar amino-acid sequence. They employ a common base-flipping, DNA intercalation strategy for substrate recognition and binding, and catalyze the hydrolysis of the $\mathrm{N}$-glycosidic bond of the substrate base, thereby generating an apyrimidinic site (AP-site). However, minor variations in the architecture of active site and the catalytic mechanism define a number of subfamilies of UDGs with distinct properties (for reviews see Pearl (2000) and Krokan et al. (2002)).

Glycosylases belonging to the UNG subfamily remove uracil residues in ssDNA as well as uracil in dsDNA paired with either adenine or guanine. Modeling of UNG based on the crystal structure of HSV-1 glycosylase shows that the base-binding pocket of the enzyme is very narrow and the arrangement of hydrogen bonds and van der Waals interactions of amino acids allows only for uracil placement but not for cytosine or thymine (Savva et al., 1995). Glycosylases belonging to the MUG/TDG subfamily are specific for the G.U/T mismatches recognized in dsDNA and exhibit only weak or no activity against the A.U base pair. In contrast to HSV-1 UNG, the E. coli Mug base-binding pocket is more spacious and is able to accommodate bulkier derivatives of bases, not only uracil or thymine (Barrett et al., 1998; Barrett et al., 1999). This can be illustrated by the fact that $E$. coli Mug excises a series of 5-halogenouracils, in which the substituent size increases from the smallest fluorine to the biggest iodine, whereas E. coli UNG acts only on 5-fluorouracil (Liu et $a l ., 2002)$.

The discovery that $3, N^{4}$-ethenocytosine $(\varepsilon \mathrm{C})$ is excised by $E$. coli Mug and by human TDG added a new type of modification recognized by this group of glycosylases (Saparbaev \& Laval, 1998; Hang et al., 1998). Modeling of $\varepsilon \mathrm{C}$ in the structure of the enzyme-substrate complex has revealed that this etheno-base is comfortably accommodated in the hydrophobic space at the bottom of $E$. coli Mug binding pocket (Barrett et al., 1999). This indicates that there is no structural constraint for the recognition and excision of $\varepsilon \mathrm{C}$ from DNA by Mug. In fact, $\varepsilon \mathrm{C}$ is excised even 50 times more efficiently from the $\varepsilon \mathrm{C} \cdot \mathrm{G}$ mismatch than $\mathrm{U}$ from the $\mathrm{U} \cdot \mathrm{G}$ mismatch (Saparbaev \& Laval, 1998).

Since E. coli Mug excises efficiently $3, N^{4}$-ethenocytosine we decided to study the excision of other, to some extent structurally similar, exocyclic hydroxyalkano adducts of cytosine (Fig. 1). We have found that all the adducts studied are excised by the Mug glycosylase, albeit with an efficiency decreasing in the order $\varepsilon \mathrm{C}>\mathrm{HEC}>\mathrm{HPC}>\mathrm{mHPC}$ (Fig. 4). We noticed that HEC and HPC are poorly excised (or not excised) within the $\mathrm{pH}$ range of 7.2-8.0 (Fig. 5), so the comparison of processing efficiencies presented in Fig. 4 is based on the results obtained from experiments performed at $\mathrm{pH} 8.6$, a $\mathrm{pH}$ value at which all studied adducts are reasonably well excised. We initially supposed that poor excision of HEC and HPC at lower $\mathrm{pH}$ is related to the fact that these adducts are quaternary bases and at lower $\mathrm{pH}$ they are in a protonated form which would result in lower enzyme affinity. This issue will be discussed in the next section.

The strong binding of glycosylases of the MUG/TDG family to DNA containing abasic sites leads to the excision of bases studied with purified enzymes proceeding slowly and demonstrating the characteristics of single turnover reaction (Hardeland et al., 2003; O'Neill et al., 2003). Consistent with that, we observed the saturation of excision of $\varepsilon \mathrm{C}$ at the relatively high enzyme/substrate ratio of $1: 4$, whereas for remaining substrates no saturation was reached even with a 5 -fold higher excess of enzyme over substrate (Fig. 4). Since the products formed by MUG type DNA glycosylases are always abasic sites, base ex- 
cision should always result in the same level of product inhibition irrespective of the nature of the substrate base. Thus, the variable processing efficiencies observed with these adducts reflect the differences in either substrate binding affinity or in the intrinsic $\mathrm{N}$-glycosidic bond stability.

In studies of non-enzymatic hydrolysis of the N-glycosidic bond of nucleosides and their analogues the reactivity of protonated species is usually examined. In this case an inverse correlation between the rate of hydrolysis and $\mathrm{p} K_{\mathrm{a}}$ of protonation was found in a series of isosteric compounds (Oivanen et al., 1993). Although the kinetic data for neutral hydrolysis are hardly available, there are some examples where the rate of hydrolysis was studied within the $\mathrm{pH}$ range embracing the $\mathrm{p} K_{\mathrm{a}}$ value. A comparison of hydrolysis of deoxycytidine and its 5-methyl and 5-bromo derivatives showed that at $\mathrm{pH}<\mathrm{p} K_{\mathrm{a}}$, an inverse, whereas at $\mathrm{pH}>\mathrm{p} K_{\mathrm{a}}$, a direct relation between basicity and the reaction rate was observed (Shapiro \& Danzig, 1972). This indicates that the higher proneness of a nucleoside to protonation (higher $\mathrm{p} K_{\mathrm{a}}$ ) is related to the lower intrinsic stability of its N-glycosidic bond. Since the observed efficiency of excision by Mug glycosylase of $\varepsilon \mathrm{C}\left(\mathrm{p} K_{\mathrm{a}}=3.7\right.$; Secrist et al., 1972), HEC $\left(\mathrm{p} K_{\mathrm{a}}=6.9\right.$; Krzyżosiak et al., 1979), HPC ( $\mathrm{p} K_{\mathrm{a}}=8.6$; this study) and mHPC ( $\mathrm{p} K_{\mathrm{a}}>7$; this study) does not correlate with the basicity of the adduct (Figs. 4 and 5), the observed differences in processing efficiencies can be related to the substrate binding affinity rather than to the N-glycosidic bond stability.

Assuming that adducts are bound in neutral form and that the geometrical positioning in the enzyme binding pocket of $3, N^{4}-\alpha$-hydroxyalkano adducts is similar to that of $\varepsilon \mathrm{C}$, the differences in enzyme-substrate affinity can be rationalized on the basis of their structural differences. The main structural difference between $\varepsilon \mathrm{C}$ and $3, N^{4}-\alpha$-hydroxyalkano adducts is the presence of polar $\mathrm{OH}$ group which could result in unfavorable interactions of these substrates with the hydrophobic space at the bottom of Mug binding pocket, in contrast to the hydrophobic $3, \mathrm{~N}^{4}$-etheno bridge of $\varepsilon \mathrm{C}$. It is apparent that the size of the $3, \mathrm{~N}^{4}$-bridge is of importance, since HEC possessing a two-carbon bridge is a better substrate than HPC possessing a three-carbon bridge. The methyl group in mHPC causes additional steric clash resulting in this crotonaldehyde adduct being the poorest substrate among those studied. The poor excision of this adduct suggests that Mug would not excise bulkier adducts, e.g. those formed by HNE or its epoxide, the main LPO products.

Using our experimental system we have confirmed that eukaryotic homologues of bacterial Mug, human hTDG and fission yeast Thp1p, are active in excision of $\varepsilon \mathrm{C}$ (Hardeland et al., 2003), however, only the yeast enzyme excises HEC and HPC (excision of mHPC was not tested). The excision of $\varepsilon \mathrm{C}$ by hTDG is rather poor, whereas excision of the three studied adducts by Thp1p occurs with high efficiency, comparable to that of the bacterial enzyme (Fig. 6). It is interesting to note that excision of $\varepsilon \mathrm{C}$ and HEC by Thp $1 \mathrm{p}$ is saturated at the lowest enzyme/substrate ratio tested, i.e. 1:8, whereas saturation of excision of HPC is reached at $1: 1$ ratio. Although an amino-acid sequence alignment of the glycosylases studied reveals some degree of conservation, especially in the catalytic core domains of the proteins (Hardeland et al., 2003), the crystal structures of hTDG and Thp1p have not been obtained yet and the detailed architecture of their active sites remains unknown. This makes a discussion on the interactions within the active sites of these enzymes pointless. It is worth noticing, however, that yeast Thp1p reveals a very broad substrate specificity which suggests that the mode of substrate interactions with this glycosylase is different than with Mug (Hardeland et al., 2003).

Previous studies in our laboratory have revealed that some undefined CAA, ACR and CRA adducts to DNA bases are excised by 
AlkA since single strand breaks are formed in plasmid DNA pretreated with these agents upon combined action of AlkA and an endonuclease (Borys \& Kuśmierek, 1998). We have found in the present study that the excision of HPC by AlkA proceeds with extremely low efficiency being about two orders of magnitude lower than by Mug, whereas $\varepsilon \mathrm{C}$ and HEC are not excised at all by AlkA under the same conditions (not shown). This indicates that AlkA excises from pretreated DNA other adducted bases rather than adducted cytosines (Borys \& Kuśmierek, 1998).

The existing reports suggest that cyclic hydroxypropano adducts to DNA bases formed by ACR and CRA are repaired via the nucleotide excision repair (NER) pathway (Marnett et al., 1985; Curren et al., 1988). Recent studies on the genotoxicity of the major ACR adduct to guanine, $1, \mathrm{~N}^{2}-\gamma$-hydroxypropanoG, also have shown that this adduct is a substrate for UvrABC-catalyzed nucleotide excision repair in $E$. coli cells (Yang et al., 2001). Our results presented here and in (Borys \& Kuśmierek, 1998) indicate, however, that some representatives of this type of adducts can also be repaired via the BER pathway, with Mug and Thp1p excising cytosine adducts and AlkA some other undefined adducts of ACR and CRA.

\section{Possible involvement of Mug lysine 68 in catalysis of hydrolysis of the glycosidic bond of exocyclic adducts of deoxycytidine}

The main difference between etheno and other adducts studied is that $3, \mathrm{~N}^{4}$-alkanobridged cytosine nucleosides are high $\mathrm{p} K_{\mathrm{a}}$ compounds, so at neutrality a substantial fraction of each adduct of this kind exists in the protonated form. Because of that we have undertaken studies on the $\mathrm{pH}$-dependence of adducts excision by Mug. The results are shown in Fig. 5. The excision of all adducts (including uracil) proceeds most efficiently within the 8.6-9.6 $\mathrm{pH}$ range. The decrease of the rate above $\mathrm{pH} 9.6$ probably reflects dena- turation of the oligonucleotide duplex and/or of the enzyme. The excision of uracil proceeds efficiently in the whole $\mathrm{pH}$ range studied (7.2-10.6) showing a small increasing tendency with the increase of $\mathrm{pH}$ up to $\mathrm{pH}$ 9.6. Liu and coworkers (2002) have also found that the cleavage of both uracil and 5-bromouracil by Mug is essentially unaffected by changes of $\mathrm{pH}$ over the range 5-9. This indicates that neutral and anionic forms of $\mathrm{U}$ and $5-\mathrm{BrU}$ ( $\mathrm{p} K_{\mathrm{a}}$ of $\mathrm{dU}$ is 9.3 and of $5 \mathrm{BrdU}$ 7.9; Berens \& Shugar, 1963) are similarly recognized by the enzyme.

The $\mathrm{pH}$-dependence curves for excision of $\varepsilon \mathrm{C}, \mathrm{HEC}$ and HPC show a distinct transition between $\mathrm{pH} 7.6$ and 8.6 (Fig. 5). The excision of $\varepsilon \mathrm{C}$ is efficient at $\mathrm{pH} 7.2-7.6$ and is further enhanced at higher $\mathrm{pH}$. In contrast, the HPC-curve reveals no excision (below $5 \%$ of cleavage, at the level of Nth control), whereas the HEC-curve reveals low excision (10-15\% of cleavage, which, however, can be attributed to the presence of some $\varepsilon \mathrm{C}$ in the preparation of the HEC 25-mer) at $\mathrm{pH} \mathrm{7.2-7.6,} \mathrm{and} \mathrm{then}$ both curves reveal an abrupt increase of excision up to $\mathrm{pH}$ 8.6. If the $\mathrm{pH}-d e p e n d e n t$ transition of excision of HEC $\left(\mathrm{p} K_{\mathrm{a}}=6.9\right)$ and HPC $\left(\mathrm{p} K_{\mathrm{a}}=8.6\right)$ can be attributed to deprotonation of these adducts, such explanation hardly applies to $\varepsilon \mathrm{C}$. The protonation of $\varepsilon \mathrm{dC}$ occurs far below $\mathrm{pH} 7\left(\mathrm{p} K_{\mathrm{a}}=3.7\right)$ and it is very unlikely that this adduct would exist in the active site of Mug in a protonated form.

We hypothesize that the observed transition in the pH-dependence of excision of $\varepsilon \mathrm{C}$ by Mug is caused by an involvement of an additional catalytic factor induced by $\mathrm{pH}$ increase. For the high $\mathrm{p} K_{\mathrm{a}}$ adducts HEC and HPC probably both factors operate. The HPC-curve is shifted towards higher $\mathrm{pH}$ values by about 0.2-0.3 pH units in comparison to the HEC-curve, which is in conformity with the $\mathrm{p} K_{\mathrm{a}}$ values of these adducts. One could expect a bigger difference since the difference in $\mathrm{p} K_{\mathrm{a}}$ values of monomers equals 1.7, however, deprotonation of substrates probably is masked by interfering of an additional factor. 
In our opinion the $\varepsilon$-amino group of Lys68 is a plausible candidate to act as the additional catalytic factor.

On the basis of the structure of the complex of Mug protein with DNA containing an abasic site, the $\varepsilon$-amino group of Lys68 was proposed to interact favorably with $\mathrm{O}^{4}$ of uracil and unfavorably with $4-\mathrm{NH}_{2}$ of cytosine, which could result in discrimination between uracil and cytosine by this enzyme (Barrett et al., 1998). However, the same authors came to different conclusions analyzing another structure, the Mug protein bound to an oligonucleotide duplex containing a G.U mispair, where the $U$ was in the form of the non-hydrolysable 2 '-fluoro-2'-deoxyuridne. In this structure the $\varepsilon$-amino group of Lys68 is directed away from the bound uracil moiety, involved in ion-pair interactions with side carboxyl groups of Asp4 and Asp71, at the surface of the protein (Barrett et al., 1999).

We suppose that an increase of the solution $\mathrm{pH}$ causes deprotonation of the $\varepsilon$-amino group of Lys68 and disruption of ion-pair interactions with the side carboxyl groups of Asp4 and Asp71. Flexibility of the four-carbon alkyl chain of Lys68 gives an opportunity for the $\varepsilon$-amino group to be shifted toward the base-binding pocket. Such an arrangement was proposed for the structure of the complex of the Mug protein with DNA containing an abasic site (Barrett et al., 1998; see above). The $\varepsilon$-amino group of Lys68 can form a hydrogen bond with the lone electron pair located on the exocyclic nitrogen atom of $\varepsilon \mathrm{C}$. It has been shown by ${ }^{15} \mathrm{~N}$ NMR that the lone electron pair of this atom is not involved in the $\pi$-orbital of $\varepsilon \mathrm{C}$ molecule and therefore it can accept a hydrogen bond (SierzputowskaGracz et al., 1984). This is in contrast to the electron pair of $4-\mathrm{NH}_{2}$ of cytosine which is involved in the $\pi$-orbital system of the pyrimidine ring and can not accept a hydrogen bond. Considering the proton accepting ability of the $\mathrm{C}^{4}$-bonded exocyclic heteroatom, $\varepsilon \mathrm{C}$ resembles rather uracil than cytosine.
Here we propose that the $\varepsilon$-amino group of Lys68 could play a role of general acid by neutralizing the negative charge which develops on the base moiety during hydrolysis of the glycosidic bond of $3, \mathrm{~N}^{4}$-bridged cytosines by Mug. Its role could be analogous to that of histidine acting as general acid in the excision of uracil by UNG (Savva et al., 1995). Since the proposed mechanism appears to operate in a relatively basic environment $(\mathrm{pH}$ around 9), it could be questionable if this mechanism is relevant to the repair of exocyclic cytosine adducts in vivo. However, in vivo interactions with other proteins would destroy the ion-pair bonding of Lys68 to aspartates at the surface of the Mug protein observed in the crystalline state and allow the $\varepsilon$-amino group of Lys68 to interact with the excised cytosine adduct.

\section{R E F E R E N C E S}

Barrett TE, Savva R, Panayotou G, Barlow T, Brown T, Jiricny J, Pearl LH. (1998) Crystal structure of a G:T/U mismatch-specific DNA glycosylase: mismatch recognition by complementary-strand interactions. Cell.; 92: $117-29$.

Barrett TE, Schärer OD, Savva R, Brown T, Jiricny J, Verdine GL, Pearl LH. (1999) Crystal structure of a thwarted mismatch glycosylase DNA repair complex. EMBO J.; 18: $6599-609$.

Barrio RJ, Secrist JA, Leonard NJ. (1972) Fluorescent adenosine and cytidine derivatives. Biochem Biophys Res Commun.; 46: 597-604.

Bartsch H. (1999) Keynote address: Exocyclic adducts as new risk markers for DNA damage in man. In Exocyclic DNA Adducts in Mutagenesis and Carcinogenesis. Singer B, Bartsch H, eds, pp 1-16. IARC Scientific Publication No. 150, IARC, Lyon.

Berens K, Shugar D. (1963) Ultraviolet absorption spectra and structure of halogenated uracils and their glycosides. Acta Biochim Polon.; 10: 25-48. 
Borys E, Kuśmierek JT. (1998) Endogenous and exogenous DNA lesions recognised by $\mathrm{N}$-alkylpurine-DNA glycosylases. Acta Biochim Polon.; 45: 579-86.

Chenna A, Iden CR. (1993) Characterization of 2 '-deoxycytidine and 2'-deoxyuridine adducts formed in reactions with acrolein and 2-bromoacrolein. Chem Res Toxicol.; 6: 261-8.

Chenna A, Rieger RA, Iden CR. (1992) Characterization of thymidine adducts formed by acrolein and 2-bromoacrolein.

Carcinogenesis.; 13: 2361-5.

Chung FL, Zhang L, Ocando JE, Nath RG. (1999) Role of $1, N^{2}$-propanodeoxyguanosine adducts as endogenous DNA lesions in rodents and humans. In Exocyclic DNA Adducts in Mutagenesis and Carcinogenesis. Singer B, Bartsch H, eds, pp 45-54. IARC Scientific Publication No. 150, IARC, Lyon.

Curren RD, Yang LL, Conklin PM, Grafstrom RC, Harris CC. (1988) Mutagenesis of xeroderma pigmentosum fibroblasts by acrolein. Mutat Res.; 209: 17-22.

Hang B, Medina M, Fraenkel-Conrat H, Singer B. (1998) A 55-kDa protein isolated from human cells shows DNA glycosylase activity toward 3, $\mathrm{N}^{4}$-ethenocytosine and the G/T mismatch. Proc Natl Acad Sci USA.; 95: 13561-6.

Hang B, Downing G, Guliaev AB, Singer B. (2002) Novel activity of Escherichia coli mismatch uracil-DNA glycosylase (Mug) excising 8-(hydroxymethyl)-3, $\mathrm{N}^{4}$-ethenocytosine, a potential product resulting from glycilaldehyde reaction. Biochemistry.; 41: 2158-65.

Hardeland U, Bentle M, Jiricny J, Schär P. (2000) Separating substrate recognition from base hydrolysis in human thymine DNA glycosylase by mutational analysis. $J$ Biol Chem.; 275: 33449-56.

Hardeland U, Bentle M, Jiricny J, Schär P. (2003) The versatile thymine

DNA-glycosylase: a comparative characterization of the human, Drosophila and fission yeast orthologs. Nucleic Acids Res.; 31: 2261-71.
Kowalczyk P, Cieśla JM, Komisarski M, Kuśmierek JT, Tudek B. (2004) Long-chain adducts of trans-4-hydroxy-2-nonenal to DNA bases cause recombination, base substitutions and frameshift mutations in M13 phage. Mutat Res.; 550: 33-48.

Krokan HE, Drablos F, Slupphaug G. (2002) Uracil in DNA - occurence, consequences and repair. Oncogene.; 21: 8935-48.

Krzyżosiak WJ, Biernat J, Ciesiołka J, Górnicki P, Wiewiórowski M. (1979) Further studies on adenosine and cytidine reaction with chloroacetaldehyde, a new support for the cyclic carbinolamine structure of the stable reaction intermediate and its relevance to the reaction mechanism and tRNA modification. Polish J Chem.; 53: 243-52.

Kuśmierek JT, Singer B. (1982) Chloroacetaldehyde-treated ribo- and deoxyribopolynucleotides. 1 . Reaction products. Biochemistry.; 21: 5717-22.

Leonard NJ. (1984) Etheno-substituted nucleotides and coenzymes: fluorescence and biological activity. CRC Crit Rev Biochem.; 15: 125-99.

Lindahl T. (1993) Instability and decay of the primary structure of DNA. Nature.; 362: 709-15.

Liu P, Burdzy A, Sowers LC. (2002) Substrate recognition by a family of uracil-DNA glycosylases: UNG, MUG, and TDG. Chem Res Toxicol.; 15: 1001-9.

Marnett LJ, Hurd HK, Hollstein MC, Levin DE, Esterbauer H, Ames BN. (1985) Naturally occurring carbonyl compounds are mutagens in Salmonella tester strain TA104. Mutat Res.; 148: 25-34.

Matijasevic Z, Sekiguchi M, Ludlum D. (1992) Release of $\mathrm{N}^{2}$,3-ethenoguanine from chloroacetaldehyde-treated DNA by Escherichia coli 3-methyladenie DNA glycosylase II. Proc Natl Acad Sci USA.; 89: 9331-4.

Oivanen M, Hovinen J, Lehikoinen P, Lönnberg H. (1993) Hydrolysis of N-glycosidic bond of nucleosides and nucleotides. Trends Organ Chem.; 4: 397-412. 
O’Neill RJ, Vorob'eva OV, Shahbakhti H, Zmuda E, Bhagwat AS, Baldwin GS. (2003) Mismatch uracil glycosylase from Escherichia coli. A general mismatch or a specific DNA glycosylase? J Biol Chem.; 278: 20526-32.

Pearl LH. (2000) Structure and function in the uracil-DNA glycosylase superfamily. Mutat Res.; 460: 165-81.

Saparbaev M, Laval J. (1998) 3,N $N^{4}$-ethenocytosine, a highly mutagenic adduct, is a primary substrate for Escherichia coli double-stranded uracil-DNA glycosylase and human mismatch-specific thymine-DNAglycosylase. Proc Natl Acad Sci USA.; 95: 8508-13.

Saparbaev M, Kleibl K, Laval J. (1995) Escherichia coli, Saccharomyces cerevisiae, rat and human 3-methyladenine DNA glycosylases repair $1, \mathrm{~N}^{6}$-ethenoadenine when present in DNA. Nucleic Acids Res.; 23: 3750-75.

Saparbaev MK, Langouet S, Privezentzev CV, Guengerich FP, Cai H, Elder RH, Laval J. (2002) $1, \mathrm{~N}^{2}$-ethenoguanine, a mutagenic DNA adduct, is a substrate of Escherichia coli mismatch-specific uracil-DNA glycosylase and human alkylpurine-DNA-N-glycosylase. $J$ Biol Chem.; 277: 26987-93.

Savva R, McAuley-Hecht K, Brown T, Pearl L. (1995) The structural basis of specific base-excision repair by uracil-DNA glycosylase. Nature.; 373: 487-93.

Secrist JA, Barrio JR, Leonard NJ, Weber G. (1972) Fluorescent modification of adenosine-containing coenzymes. Biological activities and spectroscopic properties. Biochemistry.; 11: 3499-506.

Shapiro R, Danzig M. (1972) Acidic hydrolysis of deoxycytidine and deoxyuridine derivatives. The general mechanism of deoxyribonucleoside hydrolysis. Biochemistry.; 11: 23-9.

Sierzputowska-Gracz H, Wiewiórowski M, Kozerski L, von Philipsborn W. (1984) Proton coupled ${ }^{15} \mathrm{~N}$ NMR spectra of neutral and protonated ethenoadenosine and ethenocytidine. Nucleic Acids Res.; 12: 6247-58.

Singer B, Antoccia A, Basu AK, Dosanjh MK, Fraenkel-Conrat H, Gallagher PE, Kuśmierek JT, Qiu ZH, Rydberg B. (1992) Both purified human $1, \mathrm{~N}^{6}$-ethenoadenine-binding protein and purified human 3-methyladenine-DNA glycosylase act on $1, \mathrm{~N}^{6}$-ethenoadenine and 3-methyladenine. Proc Natl Acad Sci USA.; 89: 9386-90.

Smith RA, Williamson DS, Cerny RL, Cohen SM. (1990) Detection of $1, \mathrm{~N}^{6}$-propanodeoxyadenosine in acrolein-modified polydeoxyadenylic acid and in DNA by ${ }^{32} \mathrm{P}$ postlabeling. Cancer Res.; 50: 3005-12.

Speina E, Cieśla JM, Wójcik J, Bajek M, Kuśmierek JT, Tudek B. (2001) The pyrimidine ring-opened derivative of $1, \mathrm{~N}^{6}$-ethenoadenine is excised from DNA by the Escherichia coli Fpg and Nth proteins. $J$ Biol Chem.; 276: 21821-7.

Tudek B, VanZeeland AA, Kuśmierek JT, Laval J. (1998) Activity of Escherichia coli DNA-glycosylases on DNA damaged by methylating and ethylating agents and influence of 3-substituted adenine derivatives. Mutat Res.; 407: 169-76.

Yang IY, Hossain M, Miller H, Khullar S, Johnson F, Grollman A, Moriya M. (2001) Responses to the major acrolein-derived deoxyguanosine adduct in Escherichia coli. $J$ Biol Chem.; 276: 9071-96. 